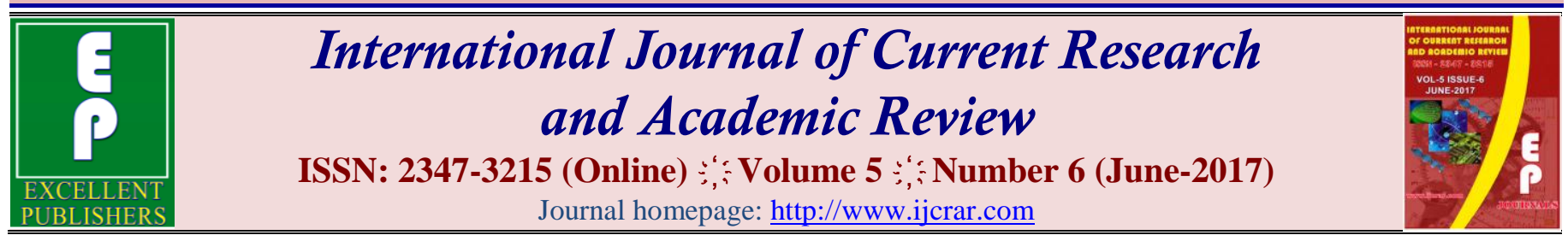

doi: $\underline{\text { https://doi.org/10.20546/ijcrar.2017.506.011 }}$

\title{
Evolution of the Vascular System-A Review
}

\author{
Teena Agrawal* and Priyanka Danai
}

Banasthali University, Niwai, India

*Corresponding author

\begin{abstract}
Evolution of the land plants was the very significant step in the development of the life. Early plants were aquatic in the nature, they were adapted to the only aquatic habitats. It was the very long evolutionary step for the development of the life on the earth: migration of the aquatic life on the land. For this development a number of the organs appears and disappears in the course of evolution (progressive and the retrogressive evolution). For the adaptation towards the land habitat a number of the modifications occur in the structures of the organism. In this series development of the vascular system was the very important aspects in the evolution of the life on the planet. Stele development was the very first step in the evolution of the vascular system. From algae to the higher spermatophytes one can see the whole development of the vascular system. Due to the vascular system and its complexity plants are able to adjust in the harsh conditions.
\end{abstract}

\section{Article Info}

Accepted: 05 June 2017

Available Online: 20 June 2017

\section{Keywords}

Adapations,

Evolution,

Vascular system,

Land plants.

\section{Introduction}

Evolution of the land plants towards the land habitat was the very significant and important step in the evolution of the plants on the diverse kind of the terrestrial habitat. Early plant life was typically aquatic .They were mostly unicellular and some filamentous in appearances. These range of the structures can be seen typically in the green algae, a number of the modifications can be observe, however some efforts for the evolution of the Plants life on the lands starts in the late Precambrian era. A series of the fossils plants can be seen and they demonstrate the evolutionary history with significant examples. Although some members of the xanthophyceae are the typical examples of the some modification towards the aquatic life, they are some ambiguous in nature (Eames, 1928). However first time steps towards the land life can be seen clearly in the case of the bryophyte. They are the amphibious in nature in the plant world, since algae are typically aquatic as well as the further groups are typically land adapted. Bryophytes have typically three classes, one of them is the Hepaticopsida, anthocerotopsida and another one is the bryopsida. In liver worts one can see the development of the early elaters, which shows the first steps towards some modification for the vascular system. Since for the first time in the evolution we can observe the modification of the tissue for the division of the labour (Harris, 1960). However there very significant role cannot be observe in whole group. Further modification of the tissue for the purpose of the development of the vascular bundles also can be observed in other groups. In anthocerotopsida first time we can observe the formation of the tissue group, which have some modification for the elaters and some other works (Arnold, 1930). However the Anthoceros like organism are typically having bryophytes natures, but some adaptations towards the early land life can be seen in these organisms (Step for the evolution of life on the earth and land habitat). 
The clear examples of the development of the vascular bundles can be seen in the pteridophytes. They are the first land plants (Stewenson, 1930). For the adaptation of the life on the land, development of the vascular tissue was the first and the significant features of the land habitat. Since in the land habitat the conditions were very harsh and tough, water availability was the another significant feature which plant has to adjust in the lines of the evolutions.
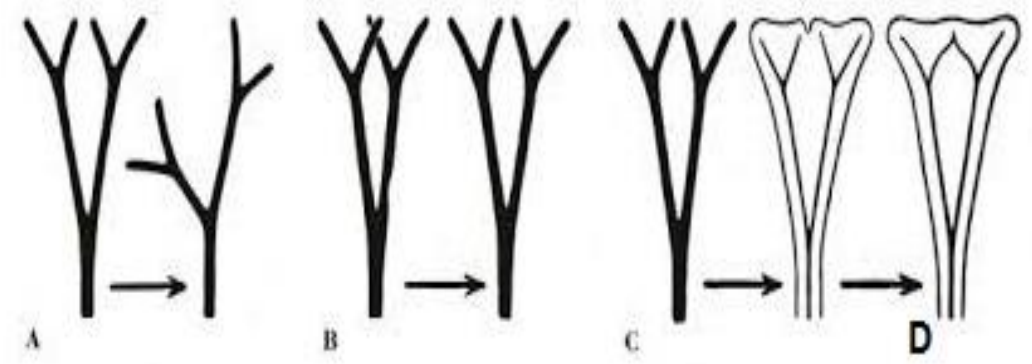

\section{evolution and development of the vascular system .}

Stele was the term which was used for the pioneering step in the evolution of the vascular bundles in the higher plants. Stele can be defined as the combinations of the tissues, which covers the certain area of the plants for the function of the transport of the water and the other minerals. Similarly for the transport of the food towards the different parts was another significant step in the development of the vascular bundles with the great complexity.

For this concept stellar theory was proposed this great theory for the development of the tissue was proposed by the Van Tieghem and Douliot (1886). According to that concepts the stele is the primary and the fundamental steps in the development of the vascular tissue, they have been considered as the central tissues for the support and the transport of the food and the mina eras as well as the water in the whole part (Fig. 1). Esau and Smith (1955) have classified the stele in two categories. One of them is the protostele and another one is the siphonostele.

\section{Protostele}

Protstele is the primitive types of the stele. In this case the core of the stele is consists of the central xylem which is surrounded by the phloem and the outer periphery $\mathrm{s}$ the pericylces and endodermis. There is no pith. The name protostele is proposed by the Jeffery (1897). Protostele is supposed to be the fundamental kind of the stele from which another kind of the stele has evolved with the differ lines of the divergence (Fig. 2).

Protostele has been classified in to the two categories.

A) Haplostele B) Actinostele

\section{Haplostele}

This is very primitive kind of the stele system, in which the core xylem is surrounded b y the uniform layer of the phloem. The organization of the xylem was of very primitives having no differentiation in to the fundamental tissue systems. Haplostele was the evolutionary first stele in the evolution $\mathrm{f}$ the plants. It has been reported in the case of the fossil plant grope of the Rhynia and the Horniophyton. In the living genera's of the Pteridophytes it has been reported in the case of the some species of the Selaginella. These species are the S. crysocaulous, $S$. kraussiana. In the Actinostele system the xylem is in the form of the star shaped. This condition can be better seen in the case of the Lycopodium serratum. Actinostele kind of the stelar system can be seen in the some fossils Pteridophytes. It has been reported in the case of the Asteroxylon. 
Fig.1

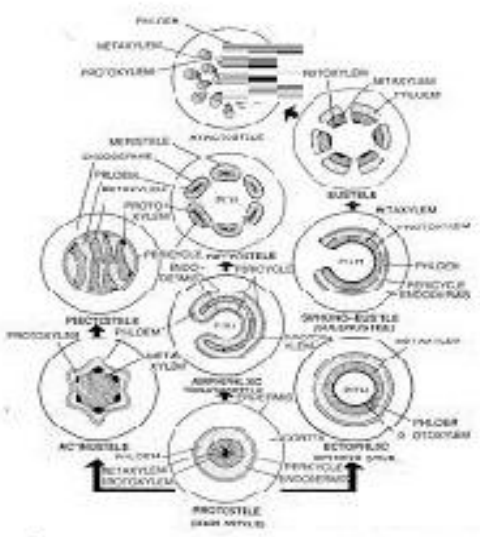

FIG ; 1 Evolution of the stele in differt lines of divergence.

Fig.2 Protostele

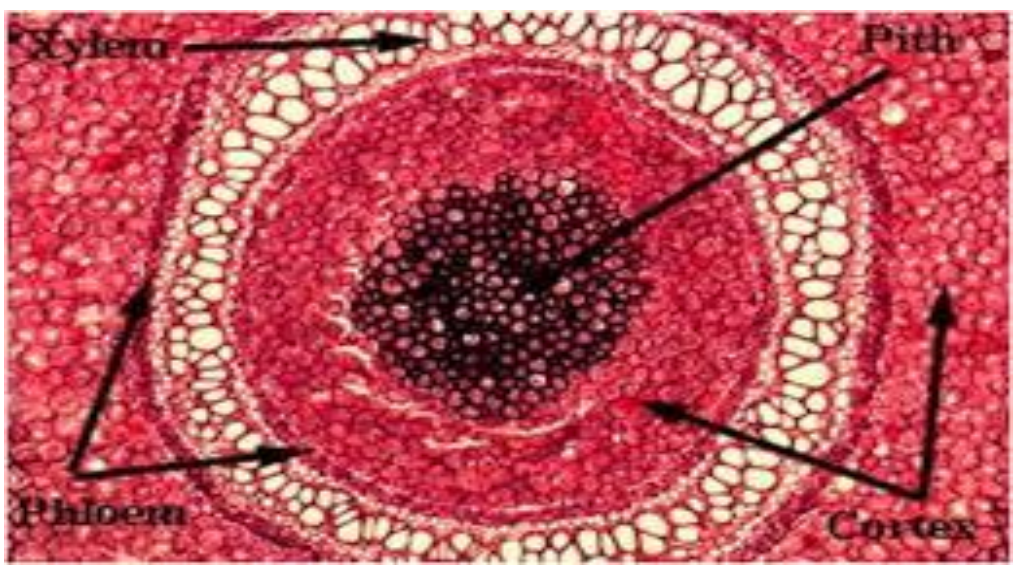

Fig.3

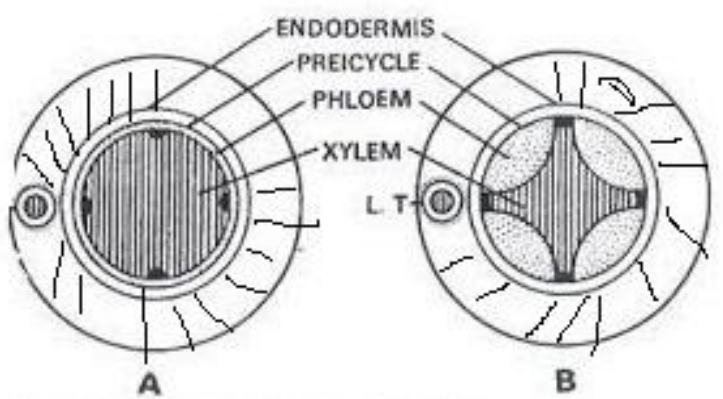

Fig : 3 types of stele 
Fig.4

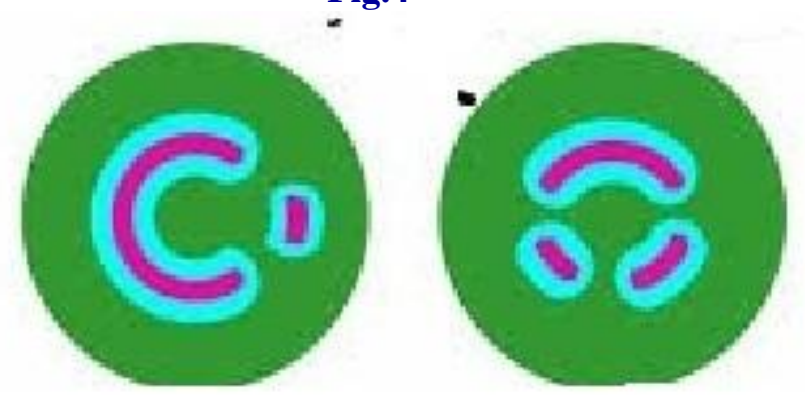

\section{FIG :4 Types of stele : solenosteel ,dictyosyele.}

The siphonostele is another significant step in the evolution stele. It was the medullated stele. It is the characteristics feature of the Filicophyta. In that stele the development of the medulla is by the formation of the some tissue in the central of the pith. In Aneimia, Phyllitidis, we can see the gradual development of the stele from lower base to the higher part of the plant group (Jeffery, 1897).

Jeffery has proposed a number of the theory for the development of the pith in the central of the xylem and the phloem.

Siphonostele has been classified in to the two categories.

1) Ectopholeic siphonostele

2) Amphipholeic siphonostele.

In the Ectopholies siphonostele the pith is surrounded by the xylem, than outer layer of the ring of the phloem, after that a layer of the pericycles and further the ring of the endodermis (Fig. 3).

Amphiphoeic endodermis is slightly complex. It is surrounded by the inner layer of the endodermis, inner layer of the pericycles and the inner layer of the phloem than xylem, after that outer layer of the phloem, outer layer the endodermis and outer layer of the pericylces.

Actinopholiec siphonostele has been reported in some of the genera enlisted as the Adiantum, Pteris, Marsilea, Dipteris. Another modification of the stele system has been observed and it has been termed as the Dictyostele, each component of the Dictyostele is termed as the Meristele. It has been reported in some members of the Dryopteris, Pteris Evolution of the stellar system: the research work done by the Jeffery (1898) shows that evolution of the stele started form the protostele. It is supposed to be the first liens of the evolution of the stele form the other ones. Modifications of the protostele lead to the development of the many other kinds of the stele. In that case modification of the stele leads to the development of the solenostele and the other kinds of the siphonostele. Dictyostele is the utmost modification of the stele system. It is found in the upper higher kinds of the ferns specially the higher ferns (Fig. 4).

There are many divergence lines of the evolutions in the development of the stele some of lines of the divergence are extinct in the lines of the evolutions, however LYCOPSID lines of the evolution is the prominent diversion of the genera 's from the lower stele to the higher stele. Fossils evidences clearly shows that new lines of the adaptation of land life.

Development of the vascular system was the very crucial step in the adaptation of the plants of the land (Easu, 1954). Complex tissue development of the xylem and the phloem with their different kind of the pattern, adapts plants in extreme and variables kinds of the land environment.

\section{References}

Arnold, Chester A. 1947. An Introduction to Paleobotany (1st edn.). New York and London: McGraw-Hill Book Company.

Bold, Harold, C., Alexopoulos, Constantine J. \& Delevoryas, Theodore. 1987. Morphology of Plants and Fungi (5th ed.). New York: Harper \& Row. 
Foster, A.S. \& Gifford, E.M. 1974. Comparative Morphology of Vascular Plants (2nd ed.). San Francisco: W.H. Freeman.

Gifford, Ernest, M. \& Foster, Adriance, S. 1988. Morphology and Evolution of Vascular Plants (3rd ed.). New York: W. H. Freeman and Company.

Stewart, Wilson, N. \& Rothwell, Gar, W. 1993. Paleobotany and the Evolution of Plants (2nd ed.). Cambridge: Cambridge University Press.

Erhorst, D.W. 1971. Morphology of Vascular Plants. In: N. H. Giles and J. G. Torrey. The MacMillan Biology Series. The MacMillan Co. New York.

Bold, H.C., C.J. Alexopoulos, and T. Delevoryas. 1987. Morphology of Plants and Fungi. 5th Edition. HarperCollins Publishers, Inc. New York.

Galtier, J. and F.M. Hueber. 2001. How early ferns became trees. Proc. R. Soc. Lond. B., 268: 19551957.

Kenrick, P. and P.R. Crane. 1997b. The Origin and Early Diversification of Land Plants: A Cladistic Study. Smithsonian Institute Press, Washington, DC.

Lellinger, D.B. 1985. A Field Manual of the Ferns and Fern-Allies of the United States and Canada. Smithsonian Institution Press, Washington, D.C.

Pearson, L.C. 1995. The Diversity and Evolution of Plants, CRC Press. New York.

Pryer, K.M., H. Schneider, A.R. Smith, R. Cranfill, P. G. Wolf, J.S. Hunt, and S.D. Sipes. 2001a. Horsetails and Ferns are a Monophyletic Group and the Closest Living Relatives to Seed Plants. Nature, 409: 618-622.

Pryer, K.M., E. Schuettpelz, P.G. Wolf, H. Schneider, A.R. Smith, R. Cranfill. 2004. Phylogeny and evolution of ferns (monilophytes) with a focus on the early leptosporangiate divergences. American $J$. Bot., 91(10): 1582-1598.

Rothwell, G.W. 1999. Fossils and ferns in the resolution of land plant phylogeny. Botanical Rev., 65: 188218.

Schneider, H., A.R. Smith, and K.M. Pryer. 2009. Is morphology really at odds with molecules in

\section{How to cite this article:}

Teena Agrawal, Priyanka Danai. 2017. Evolution of the Vascular System-A Review. Int.J.Curr.Res.Aca.Rev. 5(6), 81-85. doi: https://doi.org/10.20546/ijcrar.2017.506.011 estimating fern phylogeny? Systematic Bot., 34(3): 455-475.

Schuettpelz, E., P. Korall, and K.M. Pryer. 2006. Plastid atpA data provide improved support for deep relationships among ferns. Taxon., 55(4): 897-906.

Schuettpelz, E. and K.M. Pryer. 2007. Fern phylogeny inferred from 400 leptosporangiate species and three plastid genes. Taxon, 56(4): 1037-1050.

Schuettpelz, E. and K.M. Pryer. 2008. Fern phylogeny. In: Ranker, T. A. and C. H. Haufler, eds. Biology and Evolution of Ferns and Lycophytes. Cambridge University Press, Cambridge. pp. 395-416.

Smith, A.R., K.M. Pryer, E. Schuettpelz, P. Korall, H. Schneider, and P.G. Wolf. 2006. A classification for extant ferns. Taxon, 55(3): 705-731.

Smith, G.M. 1955. Cryptogamic Botany. Vol II. Bryophytes and Pteridophytes. 2nd ed. McGrawHill Book Co., Inc. New York.

Soria, A. and B. Meyer-Berthaud. 2004. Tree fern growth strategy in the late Devonian cladoxylopsid species Pietzschia levis from the study of its stem and root system, American J. Bot., 91(1): 10-23.

Stein, W.E., F. Mannolini, L.A. Hernick, E. Landing, and C.M. Berry. 2007. Giant cladoxylopsid trees resolve the enigma of the Earth's earliest forest stumps at Gilboa. Nature, 446: 904-907.

Stewart, W.N. and G.W. Rothwell. 1993. Paleobotany and the Evolution of Plants. 2nd edition. Cambridge University Press, Cambridge.

Thomas, B.A. and R.A. Spicer. 1987. The Evolution and Palaeobiology of Land Plants. Diocorides Press. Ecology, Phytogeography, and Physiology Series. Vol 2. Portland, Oregon.

Tomescu, A.M.F. 2008. Megaphylls, microphylls and the evolution of leaf development. Trends in Plant Sci., 14(1): 5-12.

Wikstrom, N. and K.M. Pryer. 2005. Incongruence between primary sequence data and the distribution of a mitochondrial atpl group II intron among ferns and horsetails. Mol. Phylogenetics and Evol., 36: 484-493. 